intended by Congress to control featherbedding. ${ }^{80}$ If Congress wants to control featherbedding it would seem that the NLRB would be best suited to the task. If, on the other hand, it is Congress' concern to control labor violence, there would seem to be little justification for singling out violence associated with featherbedding demands. In any event, the preservation of the peace has traditionally been a matter of state concern ${ }^{81}$ and might well be left to the states.

${ }^{80}$ But see Brown and Peer, The Anti-Racketeering Act: Labor and Management Weapon Against Labor Racketeering, 32 N.Y.U. L. Rev. 965 (1957).

${ }^{81}$ See Youngdahl v. Rainfair, 355 U.S. 131 (1957); United Auto, A. \& A.I.W. v. Wisconsin Employment Relations Board, 351 U.S. 266 (1956).

\title{
STATE IMMUNITY STATUTES AND THE SCOPE OF THE PRTVILEGE AGAINST SELF-INCRIMINATION
}

In Knapp v. Schweitzer, ${ }^{1}$ the Supreme Court decided that a witness appearing in a state proceeding under a grant of immunity against possible self-incrimination is not privileged by the Fifth Amendment to decline to answer questions on the ground of his reasonable apprehension of subsequent federal prosecution. Accordingly, the Court sustained a New York contempt citation based on Knapp's failure to reply to questions posed in the New York proceeding. The impact of the Knapp case can be understood only in the light of related precedents. ${ }^{2}$ It has been held that a state immunity statute which does not protect the witness against prosecution in another jurisdiction for the matters to which the questions relate does not violate the Due Process Clause of the Fourteenth Amendment ${ }^{3}$ and that the transcript of the witness' state testimony may be introduced against him in a federal prosecution without violating the Fifth Amendment privilege against self-incrimination, unless there was "collusion" between the two sovereigns. ${ }^{4}$ These holdings, together with the Knapp case, may place the state witness in an almost intolerable position. He may be faced with a choice between a state contempt citation if he refuses to answer, a state perjury conviction if he answers untruthfully, and a federal prosecution if he answers truthfully. ${ }^{5}$ The harshness of this possible result has caused sharp divi-

1357 U.S. 371 (1958). The result was not unexpected. See Feldman v. United States, 322 U.S. 487 (1944); United States v. Murdock, 284 U.S. 141 (1931); Jack v. Kansas, 199 U.S. 372 (1905).

2 Feldman v. United States, 322 U.S. 487 (1944); United States v. Murdock, 284 U.S. 141 (1931); Ensign v. Pennsylvania, 227 U.S. 592 (1913); Hale v. Henkel, 201 U.S. 43 (1906); Jack v. Kansas, 199 U.S. 372 (1905); I.C.C. v. Baird, 194 U.S. 25 (1904); Brown v. Walker, 161 U.S. 591 (1896); see Ableman v. Booth, 21 How. (U.S.) 506, 516 (1858). Contra: Ballman v. Fagin, 200 U.S. 186 (1906); United States v. Saline Bank, 26 U.S. 100 (1828).

${ }^{3}$ Jack v. Kansas, 199 U.S. 372 (1905).

4 Feldman v. United States, 322 U.S. 487 (1944).

${ }^{5}$ Since the analysis will not be affected thereby, this comment will assume that the witness has sound reason to fear subsequent prosecution. Although the Supreme Court, in its first enunciation of the rule that a state immunity grant need not protect the witness against 
sion on the Court ${ }^{6}$ and has evoked vigorous criticism by the commentators. ${ }^{7}$

The witness' predicament is the result of two factors: the scope of the privilege as defined by the inquiring sovereign and the determination of the prosecuting sovereign as to its use of the testimony elicited by the inquiring sovereign. A majority of the states which have addressed themselves to the first problem have indicated that the state privilege is limited to self-incrimination under the law of the inquiring sovereign. ${ }^{8}$ The Supreme Court, in deciding that the testimony may be used by the federal sovereign in its role of prosecutor, ${ }^{9}$ was influenced by the implications of our federal system. ${ }^{10}$ The Tenth Amendment precludes the federal government from preventing a state grant of immunity on the ground of an imminent federal prosecution of the witness; the Supremacy Clause $^{11}$ naturally prevents the state from granting an immunity which will prevent a subsequent federal prosecution. Thus the interaction between the determination of the scope of the privilege and the determination as to possible uses of the testimony creates tension between the purposes of the privilege against self-incrimination and the demands of the federal system.

Recognizing this tension, the Supreme Court qualified its holding in Feldman v. United States that the use of state compelled testimony in federal courts did not violate the Fifth Amendment ${ }^{12}$ by declaring that where the defendant in a

prosecution in another jurisdiction to be effective, based its decision in part on the fact that there was no substantial danger of any subsequent federal prosecution, Jack v. Kansas, 199 U.S. 372 (1905), this ground was eliminated by the holding of Feldman v. United States, 322 U.S. 487, 493-94 (1944).

${ }^{6}$ Knapp v. Schweitzer, 357 U.S. 371, 381-85 (1958) (dissenting opinions); Feldman v. United States, 322 U.S. 487, 497 (1944) (dissenting opinion); cf. Irvine v. California, 347 U.S. $128,139-40$ (1954) (dissenting opinion).

7 Grant, Federalism and Self-Incrimination, 4 U.C.L.A. L. Rev. 549 (1957); Parsons, StateFederal Crossfire in Search and Seizure and Self-Incrimination, 42 Cornell L. Q. 346 (1957); Boudin, The Immunity Bill, 42 Geo. L. J. 497 (1954); Does the Privilege against Self-Incrimination Extend to Incrimination under the Laws of Another Jurisdiction, 46 Ky. L. J. 281 (1958); Effect of Possible Federal Prosecution on Application of State Immunity Statute in State Criminal Proceedings, 11 Vand. L. Rev. 199 (1957); Admissibility in a Federal Court of Evidence Obtained under a State Immunity Statute, 53 Yale L. J. 364 (1944). The decision has also been criticized by the lower federal courts, e.g., Marcello v. United States, 196 F.2d 437, 443 (C.A.5th, 1952). The rule has had its defenders. McCormick, Evidence \$124 (1954); Brownell, Immunity from Prosecution Versus Privilege against Self-Incrimination, 28 Tulane L. Rev. 1 (1953). In the converse situation, at least one state has held that the use of testimony compelled by a federal grant of immunity in a subsequent state prosecution violates the state privilege against self-incrimination. Clark v. State, 68 Fla. 433, 67 So. 135 (1914).

88 Wigmore, Evidence $\$ 2258$ (3d. ed., 1940); McCormick, Evidence $\$ 124$ (1954).

9 Feldman v. United States, 322 U.S. 487 (1944).

10 Id., at 490-91.

11 U.S. Const. Art. 6, cl. 2.

12322 U.S. 487 (1944). The witness' confession to the state authorities is not excluded by the Fifth Amendment under the Feldman rule. Therefore, even though the witness may claim the Fifth Amendment in his role as a federal defendant, his silence at that point does not protect him against his own self-incriminating testimony. See Mr. Justice Black's dissenting opinion in the Knapp case, 357 U.S. 371,382 (1958). Anticipating this result, at least one writer has urged 
federal prosecution could prove that federal officers had participated or cooperated with state officials to procure a state grant of immunity, testimony obtained as a result of that grant would be inadmissible in the federal courts. ${ }^{13}$ This qualification was based on an analogy ${ }^{14}$ to the search and seizure cases which subject the source of state-gathered evidence offered in federal courts to federal standards when the Government is implicated in the state search.$^{15} \mathrm{How}$ ever, recent cases pointing to the conclusion that state gathered evidence which violates federal standards may be excluded in federal courts even without federal "collusion" seem to indicate the vulnerability of the federal-state dichotomy.16 In Wolf v. Colorado ${ }^{17}$ the Supreme Court declared ${ }^{18}$ that the core of the Fourth

increasing use of the immunity grant to avoid the force of the privilege. Rapacz, Limiting the Plea of Self-Incrimination and Recent Enlargement of the New York Immunity Statute, 20 Geo. L. J. 329 (1932).

${ }^{13}$ Feldman v. United States, 322 U.S. 487, 494 (1944).

14 The Court relied on Byars v. United States, 273 U.S. 28 (1927) (federal participation in a state search), and McNabb v. United States, 318 U.S. 332 (1943) (exclusion of confession obtained by federal officers by incessant questioning before arraignment).

${ }^{15}$ Evidence is excluded if a federal officer actually participates in the unlawful seizure, e.g., Lustig v. United States, 338 U.S. 74 (1949); Byars v. United States, 273 U.S. 28 (1927); if the search is made solely for the purpose of enforcing federal law, Gambino v. United States, 275 U.S. 310 (1927); Lowrey v. United States, 128 F.2d 477 (C.A.8th, 1942); if the Government delegates authority to state police and accepts prosecution of case according to a pre-arranged understanding, thereby ratifying the means whereby the searches were undertaken, Sutherland v. United States, 92 F.2d 305 (C.A.4th, 1937) (court apparently took judicial notice of state's willingness to turn over evidence when federal violations were uncovered); Fowler v. United States, 62 F.2d 656 (C.A. 7th, 1932); but see United States v. Haywood, 208 F.2d 156 (C.A. 7 th, 1953) (defendant must prove not merely an established practice of cooperation, but an agreement to make unlawful searches and seizures); cf. Rios v. United States, 256 F.2d 173 (C.A.9th, 1958) (even though California had acquitted defendant on basis of its exclusionary rule, Government could secure conviction on same evidence). A mere "tip" from a federal officer does not establish custom or cooperation, e.g., Shurman v. United States, 219 F.2d 282 (C.A.5th, 1955); Rent v. United States, 209 F.2d 893 (C.A.5th, 1954); Fredericks v. United States, 208 F.2d 712 (C.A.5th, 1953); Scotti v. United States, 193 F.2d 644 (C.A.5th, 1952); Sloane v. United States, 47 F.2d 889 (C.A.10th, 1931). Unilateral understanding by state officers that they were at liberty to refer cases to the Government, who might or might not accept them, though this was frequently done, does not constitute sufficient cooperation, e.g., Kitt v. United States, 132 F.2d 920 (C.A.4th, 1942). Such cases have given rise to the "silver platter" doctrine, e.g., Weeks v. United States, 232 U.S. 383 (1914); Gaitan v. United States, 252 F.2d 256 (C.A.10th, 1958) (search completed before federal officers told of violation or entered defendant's apartment); Andersen v. United States, 237 F.2d 118 (C.A.9th, 1956) (federal officer gave phone number of Secret Service on request of state police after illegal search); Gallegos v. United States, 237 F.2d 694 (C.A.10th, 1956); United States v. White, 228 F.2d 832 (C.A.7th, 1956); Jones v. United States, 217 F.2d 381 (C.A.8th, 1954); United States v. Stirsman, 212 F.2d 900 (C.A.7th, 1954); Shelton v. United States, 169 F.2d 665 (App. D.C., 1948). Cf. Benanti v. United States, 355 U.S. 96 (1957).

${ }^{16}$ See The Benanti Case: State Wiretap Evidence and the Federal Exclusionary Rule, 57 Col. L. Rev. 1159, 1163-64 (1957).

17338 U.S. 25 (1949) (dictum). See Allen, The Wolf Case: Search and Seizure, Federalism, and the Civil Liberties, 45 Ill. L. Rev. 1 (1950).

${ }_{18}$ The Court has since repeated its adherence to the view first announced in the Wolf case. Irvine v. California, 347 U.S. 128, 132 (1954); Stefanelli v. Minard, 342 U.S. 117, 119 (1951). 
Amendment-protection against intrusion of privacy-is included in the Due Process Clause of the Fourteenth Amendment. That declaration weakens the basis for admission in federal courts of evidence independently gathered by state officers since the customary ground for receiving the evidence has been that no part of the Federal Constitution was violated.19 Although the lower federal courts have divided as to the impact of the Wolf case on the admissibility of such state gathered evidence, ${ }^{20}$ the most recently reported decision, Hanna v. United States, ${ }^{21}$ has excluded in a federal court evidence independently gathered by state officers in violation of the Fourteenth Amendment.

Since state gathered evidence obtained in violation of the Federal Constitution is admissible in state courts, ${ }^{22}$ the deterrent effect on state officers of exclusion of the same evidence in federal courts is negligible. ${ }^{23}$ The unavailability of a strong deterrence rationale suggests that the Hanna case may indicate an unwillingness to permit the federal government to do indirectly what it cannot do directly-obtain a conviction based on illegally secured evidence. The implications of this interpretation for the self-incrimination cases are obvious. Even though the use of a state grant of immunity for state purposes cannot be denominated an illegal method of obtaining evidence, the Hanna approach, if followed in the search and seizure cases, ${ }^{24}$ may yet invite the Court to foreclose such circuitous routes of investigation to the federal government in the selfincrimination area even where there has been no federal-state "collusion."

In the Knapp case, however, even petitioner's reliance on the "collusion" doctrine proved unavailing. Although the lower New York courts assumed that the Feldman collusion limitation would protect Knapp against Federal prosecution on the basis of his testimony, ${ }^{25}$ the Supreme Court, while affirming the

19 E.g., Weeks v. United States, 232 U.S. 383, 398 (1914).

${ }^{20}$ Compare Hanna v. United States, 260 F.2d 723 (App. D.C., 1958), and Jones v. United States, 217 F.2d 381 (C.A.8th, 1954), with United States v. Moses, 234 F.2d 127 (C.A.7th, 1956); United States v. White, 228 F.2d 832 (C.A.7th, 1956); Fredericks v. United States, 208 F.2d 712 (C.A.5th, 1953); Serio v. United States, 203 F.2d 576 (C.A.5th, 1953).

21260 F.2d 723 (App. D.C., 1958). Cf. Hurd v. Hodge, 334 U.S. 24, 35 (1948), where the Court, as an alternative ground for decision, refused to compel specific performance of a restrictive covenant in the District of Columbia because "[i]t is not consistent with the public policy of the United States to permit federal courts in the Nation's capital to exercise general equitable powers to compel action denied the state courts where such state action has been held to be violative of the guaranty of the equal protection of the laws."

22 Wolf v. Colorado, 338 U.S. 25 (1949).

23 "Perhaps the sanction of excluding such evidence from federal trials has a greater deterrent effect upon federal officers than upon state officers. But there is no calculus to measure such a difference, nor is it the kind of difference which warrants opposite conclusions as to the admissibility of the evidence." Hanna v. United States, 260 F.2d 723, 728-29 (App. D.C., 1958).

24 "It has remained an open question in this court whether evidence obtained solely by state agents in an illegal search may be admissible in federal court despite the Fourth Amendment." Benanti v. United States, 355 U.S. 96, 102 n.10 (1957).

${ }^{25}$ Knapp v. Schweitzer, 2 A.D.2d 579, 585, 157 N.Y.S.2d 158, 165 (1956), aff'd without opinion 2 N.Y.2d 913, 141 N.E.2d 825 (1957). 
conviction, rejected the applicability of that doctrine to the $K n a p p$ case. ${ }^{26}$ Three members of the Court, ${ }^{27}$ urging that the state courts should have been corrected on this point of federal law, wanted to remand the case for reconsideration.28 Had this procedure been followed, New York would have been faced with the problem of deciding whether a grant of New York immunity would have been sufficient to replace the scope of the New York privilege despite the fact that a subsequent federal prosecution could be based on the testimony compelled thereby or on possible leads from that testimony.29 A rational solution of this problem presupposes a re-examination of the rationale for the privilege.

It is familiar learning that the privilege against self-incrimination is rooted in the historic struggle of Englishmen against the use of the oath ex officio as an interrogation technique and the all too frequent physical torture of the accused. ${ }^{30}$ Many conflicting explanations have been suggested for the privilege. Bentham's classic challenge of the privilege urged that it is the result of a misplaced sentimentality ${ }^{31}$ and that it is a sort of "fair chance" given to the accused resembling the Englishman's notion of sportsmanship. ${ }^{32}$ Wigmore has suggested that its main purpose at the trial stage is to encourage the police to engage in more effective investigation as the basis for prosecution. ${ }^{33}$ However, Professor Meltzer has persuasively suggested that the correct rationale for the privilege is that it is a realistic recognition that not even the law can command the impossible result of requiring a criminal defendant to condemn himself by truthful testimony..$^{34}$ This justification rests on the law of self-preservation urged in the Trial of Lilburn and Wharton: ${ }^{35}$ the law is humane enough to refrain from de-

${ }^{26}$ Knapp v. Schweitzer, 357 U.S. 371 (1958).

${ }^{27}$ Chief Justice Warren, Justices Black and Douglas dissenting, Knapp v. Schweitzer, 357 U.S. 371, 381, 382 (1958).

${ }^{28}$ This procedure has occasionally been employed by the Court, e.g., Standard Oil Co. v. Johnson, 316 U.S. 481 (1942).

${ }^{29}$ It is true that New York has held that its immunity statute need only protect against New York prosecution, Dunham v. Ottinger, 243 N.Y. 423, 438, 154 N.E. 298, 302 (1926), following Hale v. Henkel, 201 U.S. 43 (1906), and Brown v. Walker, 161 U.S. 591 (1896). But the decision seems based purely on precedent, and there is no attempt to examine the rationale of the privilege. Even if New York would have decided the Knapp case the same way upon a remand on the authority of the Dunham case, this possibility does not invalidate the text discussion that the crucial problem is one of the re-examination of the scope of the privilege by all the states.

${ }^{30}$ Morgan, The Privilege Against Self-Incrimination, 34 Minn. L. Rev. 1 (1949); Pittman, The Colonial and Constitutional History of the Privilege Against Self-Incrimination in America, 21 Va. L. Rev. 763 (1935).

315 Bentham, Rationale of Judicial Evidence 207, 230-38 (1827).

32 Id., at 238.

33 8 Wigmore, Evidence \$2251 (3d ed., 1940), at 309.

${ }^{34}$ Meltzer, Required Records, The McCarran Act, and The Privilege Against Self-Incrimination, 18 U. of Chi. L. Rev. 687, 692-93 (1951).

${ }^{35} 3$ How. St. Tr. 1315, 1332 (1637), quoted in Meltzer, id., at 692. 
manding that the defendant choose between "perjury, recalcitrance, or confession." ${ }^{36}$ The latter rationale applies not only to the privilege given to the criminal defendant at the trial stage, but also to the state witness who, while testifying under an immunity grant, still fears subsequent federal or sister-state prosecution. Thus, the self-preservation analysis implies that whenever the person being questioned is offered the alternatives of perjury, recalcitrance, or confession, he should be allowed to invoke the privilege. Three cases may be postulated to illustrate this hypothesis. In the first, the witness is not granted immunity. He does not face the harsh alternatives because he may halt the line of inquiry by a proper claim of the privilege as soon as he realizes that he may no longer respond with safety. Nor is the witness placed in this position in the second case where he is testifying under a grant of state immunity and he could fear only prosecution by the state making the grant. When a single sovereign is involved and the witness' fear of prosecution is directed solely to that sovereign, the grant of immunity removes the pressure on the witness by nullifying the threat of prosecution which generated the pressure. In the second case the grant effectively replaces the scope of the privilege; for the witness is completely protected by the immunity granted in exchange for his testimony. But, in the third case, where the witness fears prosecution from two sovereigns and is granted immunity only by the inquiring sovereign, all of his fears are not allayed. ${ }^{37} \mathrm{It}$ is submitted that a witness in the third case faces substantially the same impossible choice confronting a criminal defendant in the absence of the privilege. Moreover, if such a witness is a suspect under grand jury or legislative investigation, he may be confronted with similar unpleasant alternatives: although the state will not prosecute him, the federal government or a sister state may well decide to do so. The state, in order to secure a quid pro quo for its immunity, will seek to maximize the witness' disclosure. If he responds to the fear of prosecution from another jurisdiction, the self-preservation analysis suggests that recalcitrance or perjury may result. If he overcomes his fears, his truthful testimony will facilitate the preparation by the second sovereign of the case against him. Thus, the Feldman rule may result in frustration of either the grant of immunity, the privilege against self-incrimination, or possibly of both.

Accordingly, the rationale of self-preservation should operate to extend the prosecution of the state privilege to the state witness who fears prosecution either from the federal government or from a sister state..$^{38}$ If the state privilege

${ }^{36}$ Meltzer, op. cit. supra note 34, at 393.

37 "Feldman places a witness who is called before a state agency and ordered to testify in a desperate position; he must either remain silent and risk state imprisonment for contempt or confess himself into a federal penitentiary." Knapp v. Schweitzer, 357 U.S. 371, 384-85 (1958) (Mr. Justice Black, dissenting).

${ }^{38}$ It should be noted that the administrative problems are different in the state-federal and the state-state case. In the first case, the state court only has to discover the laws of one sovereign; in the second, the state may have to pass on the reasonableness of a claim of the privilege according to any one of forty-eight other state laws and the federal law. Although this problem 
were interpreted to extend to a witness who reasonably feared subsequent prosecution from another sovereign, the state immunity statute would not displace the privilege because the scope of the immunity must be co-extensive. with the scope of the privilege. ${ }^{39}$ Viewed in this light, the Court's ruling in Jack v. $K a n s a s^{40}$ that the immunity need only protect against prosecution by the jurisdiction making the inquiry seems too narrow because it cannot be squared with a rational justification for the privilege. Local immunity is not in fact the equivalent of the privilege when there is fear of prosecution outside the jurisdiction. Under existing constitutional law, such an interpretation of the state privilege is wholly a matter for state court determination free from the compulsion of federal constitutional doctrine. By judicial decision Michigan and three states ${ }^{41}$ following the "Michigan rule" have already so interpreted their privileges against self-incrimination; at least one state by statute ${ }^{42}$ will not grant immunity when it reasonably appears that the testimony which would be compelled might subject the witness to prosecution under the laws of another state or of the United States.

The "Michigan rule" reflects an awareness of the rationale of the privilege in its recognition that subsequent federal use of state testimony would defeat the purposes of the state privilege. Nevertheless, the majority in the $K n a p p$ case did not choose to reconsider the Feldman holding that such subsequent federal use

is lessened in the states which have adopted the Uniform Proof of Statutes Act, 9A U.L.A. 246, 247 (1957), many states still require that the law of sister states be pleaded and proved, McCormick, Evidence $\$ 326$ (1954). General provision for judicial notice in this situation would appear to be a needed reform. Problems of extradition, not present in the state-federal case, can arise in the state-state case. It is, of course, possible for a state to deny extradition of the witness to a requesting state since the extradition provision, U.S. Const. Art. IV, sec. 2. cl. 2 , has been construed to be voluntary rather than mandatory, Kentucky v. Dennison, 24 How. (U.S.) 66 (1861). But see the Uniform Criminal Extradition Act, 9 U.L.A. 258 (1957). It has been held, however, that the fact that a defendant was made amenable to the jurisdiction of the prosecuting state by kidnapping does not nullify the conviction, Frisbie v. Collins, 342 U.S. 519 (1952), Ker v. Illinois, 119 U.S. 436 (1886).

${ }^{39}$ Counselman v. Hitchcock, 142 U.S. 547 (1892) (construing a federal immunity statute by the standard of the Fifth Amendment); Jack v. Kansas, 199 U.S. 372 (1905) (construing a state immunity statute by the standard of the Fourteenth Amendment).

40199 U.S. 372 (1905).

${ }^{1}$ Florida, Kentucky and Louisiana. State v. Kelly, 71 So.2d 887 (Fla.Sup.Ct., 1954); Commonwealth v. Rhine, 303 S.W.2d 301 (Ky.Ct. of App., 1957); State ex rel Doran v. Doran, 215 La. 151, 39 So.2d 894 (1949); People v. Den Uyl, 318 Mich. 645, 29 N.W.2d 284 (1947); cf. State v. Dominquez, 228 La. 284, 82 So.2d 12 (1955) (holding a witness may invoke the federal Fifth Amendment in the state court when the danger stems from the federal government). All these cases extend the protection of the state privilege only when the state witness can show substantial or imminent peril of prosecution by the second sovereign. The majority of states do not follow this rule. See 8 Wigmore, Evidence \$2258 (3d. ed., 1940); McCormick, Evidence \$124 (1954).

42 Mllinois. Ill. Rev. Stat. c. $38 \$ 580$ a (1957). Illinois added this provision to the Model State Witness Immunity Act, 9C U.L.A. 186 (1957). For an interpretation of the Illinois statute, see People v. Burkert, 7 Ill.2d 506, 131 N.E.2d 495 (1955). 
of the state testimony would not impair the purposes of the Fifth Amendment. Mr. Chief Justice Warren observed, however, that "a satisfactory solution cannot be reached without a reconsideration of that decision"43 and Mr. Justice Brennan, concurring, explicitly stated his opinion that the $K n a p p$ decision did not foreclose reconsideration of Feldman.44

Such reconsideration, presumably, would deal with at least three possible solutions. Perhaps the most obvious choice is to retain the Feldman rule. At least one commentator has remarked that "it is hard to see how any different holding could be justified." 45 Yet, in view of the criticisms of the Feldman rule $^{46}$ and the doubts of some members of the present Court, ${ }^{47}$ such a facile solution of the problem appears unlikely. As explained by Mr. Justice Frankfurter, ${ }^{48}$ the Feldman result is the "price of federalism." ${ }^{49}$ But plainly the position of the witness under a set of doctrines which treats each of the sovereigns as if it were the only one involved seems incompatible with a meaningful rationale for the privilege. The view that the two sovereigns are entirely separate in their respective spheres cannot obscure the fact that, in the federal-state case, both act upon the same citizen. The federalist concept does not operate to remove the state witness' fear of subsequent federal prosecution. Moreover, it may be doubted that the sharp separation of power envisaged by classical federalism accords with the actuality of modern federalism. It is often the case that both sovereigns may desire to prosecute the actor for different aspects of the same series of acts. ${ }^{50}$ Furthermore, in some cases, such as the federal gambling tax, the federal law has no other real purpose save to aid the states in enforcing their own laws. ${ }^{51}$ Finally, the praiseworthy day-to-day cooperation of the Federal Bureau

${ }^{43}$ Knapp v. Schweitzer, 357 U.S. 371, 382 (1958).

4 Id., at 381.

${ }^{45}$ McCormick, Evidence $\$ 124$, at p. 261 n.14 (1954).

${ }^{45}$ See authorities cited in note 7 supra.

${ }^{47}$ Feldman was a 43 decision. Two of the dissenters, Justices Black and Douglas, are still on the Court. Mr. Chief Justice Warren and Mr. Justice Brennan expressed their doubts in their opinions in the Knapp case. See notes 43 and 44 supra.

${ }^{48}$ Knapp v. Schweitzer, 357 U.S. 371, 375-80 (1958); Feldman v. United States, 332 U.S. $487,490-91$ (1944).

${ }^{19}$ Knapp v. Schweitzer, 357 U.S. 371, 380-81 (1958).

${ }^{50}$ It may be argued that a distinction should be drawn between those cases in which the primary interest is federal and those in which the primary interest is local. In part, such a distinction has already been drawn. That is, it has been held that the federal government may grant an immunity binding on the states, Ullmann v. United States, 350 U.S. 422 (1956), and the lower courts have construed that holding as limited to cases involving the national security, Tedesco v. United States, 255 F.2d 35, 39 (C.A.6th, 1958). However, it is clear that the states lack power to bind the federal government when the state interest is paramount. But it would seem that a stronger argument could be made for extending federal comity to state immunity grants where the primary interest is a state one.

${ }^{51}$ Cf. United States v. Kahriger, 345 U.S. 22 (1953). 
of Investigation and other federal agencies with state law enforcement bodies is a common illustration of the power of the states and federal government united against the criminal..$^{52}$ It would seem that the Feldman view of the two isolated sovereigns not only fails to take account of the practical workings of modern federalism, but also fails to give full scope to the rationale of the privilege.

Another approach to the Feldman problem would bar admission of the state testimony and its fruits in the federal courts while allowing a federal prosecution of the state witness based upon independently obtained evidence. This approach would avoid the criticism of the classical federalists: the federal government would not be prevented from prosecution by the state grant; it would merely be deprived of an evidentiary windfall. Indeed, the proposed solution could be effected in two ways. The Supreme Court could either interpret the Fifth Amendment to bar the admission of all self-incriminating testimony extracted by the use of a state immunity statute ${ }^{53}$ or it could exclude such testimony through its power to supervise the administration of federal justice..$^{54}$ But despite stringent application of the "fruits of the poisonous tree" doctrine, it seems clear that once the prosecuting jurisdiction was informed of the state testimony some clues could be gleaned therefrom. Absent proper allocation of the burden of proof as to the source of the evidence, ${ }^{65}$ the witness would, to some extent, have aided in his own prosecution. In any event, fearing that result, the witness might prefer perjury or recalcitrance to reliance on the "poisonous fruits" doctrine. On the other hand, the Court, through its desire to protect the

${ }^{62}$ Allen, The Supreme Court, Federalism, and State Systems of Criminal Justice, $8 \mathrm{U}$. of Chi. L.S. Rec. 3 (1958). Professor Allen, after mentioning the Mann Act, the Harrison Act, the Dyer Act, the Lindbergh Law and the Fugitives from Justice Act, concluded as follows: "This legislation, in the most direct and significant fashion, introduced federal personnel and federal power into the area of even routine law-enforcement. . . . The importance of training programs for state police officers, conducted by such agencies as the Federal Bureau of Investigation and the Narcotics Bureau, and the service functions of federal agencies, such as the maintenance of fingerprint files and scientific aids to detection available to state law enforcement, should not be underestimated. The net result of these federal activities has been to render wholly inadequate the traditional concept of rigid separation of federal and state powers in criminal law enforcement. On the contrary, a new system of cooperative federalism has appeared, the full significance of which has not been grasped by the public at large and, indeed, has only begun to be appreciated by many persons professionally engaged in law-enforcement functions." (Italics added.)

${ }^{53}$ Feldman v. United States, 322 U.S. 487, 496-97 (1944) (Mr. Justice Black, dissenting).

54 Examples of the Court's use of this power are Weeks v. United States, 232 U.S. 383 (1914) (federal exclusionary rule of evidence gained by an illegal search and seizure conducted by federal officers), and McNabb v. United States, 318 U.S. 332 (1943) (announcing the federal "speedy arraignment" rule). If the Court were to adopt a similar exclusionary rule for state compelled immunity testimony, presumably the decision would not have the status of a Constitutional determination.

${ }_{55}$ It may be suggested that the prosecution should be made to carry this burden because of its superior access to the evidence. The witness would first be required to prove that the prosecution had been informed of the testimony, and such proof would cause the burden of showing that the testimony had not been used in any way to shift. For an analysis of this problem, see The Use of State-Compelled, Self-Incriminating Testimony in Federal Courts, 68 Yale L. J. 322 (1958). 
defendant, might find links between the state testimony and the prosecution's evidence where none existed in fact.

A third solution to the Feldman problem would appear to rest with the policy branch of the prosecuting forum-be it the federal government or a sister state. The prosecuting attorney could be empowered to respect the state grants of immunity by refusing to use the testimony or its fruits in the investigation or prosecution of the witness for the matters to which the questions related. If the states adopted the "Michigan rule," extension of comity by the prosecuting forum would be necessary only in cases where the witness had not been able to establish a reasonable apprehension of future prosecution. However, comity could be extended to a state which followed the majority view as to the scope of the state privilege; if this were done, the witness would be adequately protected against the use of his testimony by the prosecuting forum.

If reconsideration of the Feldman decision would lead to the exclusion of state compelled testimony in federal courts, the harsh effect of the Knapp case on the witness' position would be lessened. Without such reconsideration, the impact of Knapp cannot be mitigated, unless a persuasive ground for overruling it can be found. The suggestion of the Knapp case that the witness could claim the Fifth Amendment in a state court if he could prove federal participation in procuring the grant of immunity ${ }^{56}$ offers the barest minimum of protection because of the difficulty of securing such proof. ${ }^{57}$ Nor is the argument that the Supreme Court should have solved the Knapp problem by using the Due Process Clause of the Fourteenth Amendment to impose the "Michigan rule" on the states a sound one. That argument employs the coerced confession rule as an analogy. The Court has held that a state conviction based on a confession coerced by physical violence, ${ }^{58}$ psychological pressure ${ }^{59}$ or long periods of illegal detention ${ }^{60}$ violates the Due Process Clause. The coerced confession rule is designed to achieve at least two objectives: maintenance of the "fair trial" standard by excluding unreliable evidence and deterrence of improper methods of police investigation. Since a similar explanation may be given for the historic justification of the

${ }^{56}$ Knapp v. Schweitzer, 357 U.S. 371,380 (1958). It may be argued that if the witness can prove sufficient cooperation before testifying to enable him to invoke the federal privilege in the state proceedings, he could also use the same proof to prevent a subsequent prosecution based upon that testimony. Yet it is apparent that, given only a choice as to which point in time the cooperation proof should be used, the witness would strongly prefer to remain silent. He is well advised to do so, for no matter how stringent an exclusionary rule is used to effectuate the cooperation limitation there remains a risk that the prosecution will gain important leads from the testimony.

${ }^{57}$ The Use of State-Compelled, Self-Incriminating Testimony in Federal Courts, 68 Yale L. J. 322, 326-34 (1958).

${ }^{58}$ Brown v. MIississippi, 297 U.S. 278 (1936); Chambers v. Florida, 309 U.S. 227 (1940); White v. Texas, 310 U.S. 530 (1940).

56 Watts v. Indiana, 338 U.S. 49 (1949).

${ }^{60}$ Ashcraft v. Tennessee, 322 U.S. 143 (1944). 
privilege against self-incrimination, ${ }^{61}$ there would seem to be some connection between coerced confessions and the privilege. It is, accordingly, arguable that since coerced confessions are prohibited under the Due Process Clause, it would appear that some elements of the privilege are also included in that clause. Moreover, so runs the argument, even if the foregoing analysis is not completely persuasive, the factual similarities of the coerced confession and the testimony compelled under a grant of immunity are close enough so that the latter should be viewed as a coerced confession when the witness is faced with subsequent prosecution. ${ }^{62}$

Under existing doctrine, the obstacles to such an argument would appear to be insurmountable. The analogy between a coerced confession with its overtones of physical violence inherent in a back room atmosphere and the orderly procedure surrounding an immunity grant leaves much to be desired. Furthermore, there are no Supreme Court cases holding that the federal government could not use a state coerced confession in a federal prosecution, and it has been held that one state may use a confession coerced by a sister state. ${ }^{63} \mathrm{It}$ is true that the Court excluded from a federal trial a confession coerced by a foreign detective in a foreign country, but the crime was committed aboard an American vessel on the high seas, and the coercion took place while the defendant was being held under the direction of the American consul. ${ }^{64}$ But the most serious difficulty with the due process argument is that it runs counter to established precedent. The Court has declared that the privilege against self-incrimination is neither a privilege or immunity of federal citizenship under the Fourteenth Amendment nor a component of due process. ${ }^{65}$ Indeed, the Court has suggested (although one may doubt whether the present Court would agree) that a state could repeal its own privilege against self-incrimination without violating the Fourteenth Amendment. ${ }^{66}$ If the plight of a criminal defendant stripped of the privilege does

61 See note 30 supra.

${ }^{62}$ Knapp v. Schweitzer, 357 U.S. 371, 384 n.2 (1958) (Mr. Justice Black, dissenting).

${ }^{63}$ Gallegos v. Nebraska, 342 U.S. 55 (1951). It is true that the Texas coerced confession was verified by Nebraska before Gallegos was charged with murder, id., at 69 , and it may be argued that neither the unreliability nor the deterrence explanations were present in this case since exclusion of the confession in the Nebraska proceedings would not deter the Texas police from future violations. Thus the precedent value of this case may be weakened by arguing that the rule was not applied because the reasons which support the rule were absent.

${ }^{64}$ Bram v. United States, 168 U.S. 532 (1897). The Court does not discuss the two sovereignties problem.

${ }^{65}$ Twining v. New Jersey, 211 U.S. 78, 99, 112-14 (1908) ("for the reasons given, we think that the exemption from compulsory self-incrimination in the courts of the States is not secured by any part of the Federal Constitution," id., at 114), reafirmed in Palko v. Connecticut, 302 U.S. $319,323,325$ (1937); Adamson v. California, 332 U.S. 42, 53 (1947); and Knapp v. Schweitzer, 357 U.S. 371, 374 (1958) (as to privileges and immunities only). See McCormick, Evidence $\$ 121$ (1954).

${ }^{66}$ Twining v. New Jersey, 211 U.S. 78, 112-13 (1908); Palko v. Connecticut, 302 U.S. 319, 323-24 (1937) ("The Fifth Amendment provides also that no person shall be compelled in any 
not violate the notion of "ordered liberty," a fortiorori, the plight of a witness testifying under a grant of immunity would not violate that notion.

Plainly, any solution involves a sacrifice of either the freedom of each sovereign or of the scope of the privilege against self-incrimination. And there is no formula by which those who believe that the privilege is an important safeguard of human rights can demonstrate its value. Yet the position of a witness who reasonably fears federal prosecution is an unenviable one which should invite serious reflection about the Feldman rule and its "price of federalism" rationale. Perhaps the best solution would be a three-part state-federal one: overruling of the Feldman case by the Supreme Court; acceptance by the states of the interpretation of the privilege suggested by the "Michigan rule;" and voluntary extension of comity by the prosecuting sovereign to immunity grants in those cases where the state witness had been unable to demonstrate the threat of subsequent prosecution and therefore testified before the state proceedings.

criminal case to be a witness against himself. This Court has said that, in prosecutions by a state, the exemption will end if the state elects to end it. Twining v. New Jersey ...").

${ }^{67}$ Palko v. Connecticut, 302 U.S. 319, 325 (1937). 